\title{
Class management implementation to boost the standard of teaching teachers
}

\author{
Lindah Lestari ${ }^{1}$, Happy Fitria ${ }^{2}$, Rohana Rohana ${ }^{2}$ \\ ${ }^{1}$ Sekolah Menengah Atas Negeri 1 Babat Supat, Indonesia \\ ${ }^{2}$ Universitas PGRI Palembang, Indonesia
}

\section{Article Info}

\section{Article history:}

Received Jul $15^{\text {th }}, 2021$

Revised Aug $3^{\text {th }}, 2021$

Accepted Aug 30 ${ }^{\text {th }}, 2021$

\section{Keyword:}

Classmanagement

Quality of teacher teaching

\begin{abstract}
The purpose of this study was to describe the implementation of the management of the classroom in order to improve the teaching quality of SMA Negeri 1 Babat Supat teachers. The principal and teachers were the sources of data for this research. Techniques for data gathering: 1) observation, (2) interviews, (3) documentation. Techniques for Data Analysis (1) data reduction, (2) presentation of data, (3) verification of data. The results of the observations of the researcher included: 1) Learning Implementation Plan (RPP), 2) Teacher appearance, 3) Opening and closing teacher activities, 4) Teacher activities varying learning stimuli, 5) Teacher activities questioning skills, and 6) Reinforcement teacher activities are said to be good because they refer to the components of the K13 curriculum. The barriers faced by this study were: (1) students did not pay attention to the material; (2) a limited number of supporting media; (3) the learning environment is not conducive; (4) students are usually passive in answering questions; (5) heterogeneous students are less concerned with education; (6) instilling character in students (lack of discipline).
\end{abstract}

(C) 2021 The Authors. Published by IICET.

This is an open access article under the CC BY-NC-SA license

(https://creativecommons.org/licenses/by-nc-sa/4.0

\section{Corresponding Author:}

Lindah, L.,

Sekolah Menengah Atas Negeri 1 Babat Supat, Indonesia

Email: iin31184@gmail.com

\section{Introduction}

An important factor in helping teachers control classroom learning is class management. The significance of classroom management is due to the approach of the teacher to the implementation of management functions assigned to the field of learning.The competence of teachers is connected to the power to perform their duties, which is to use the field of study as a learning material that acts as an instructional tool and pedagogical competence related to the teacher's role in paying attention to the actions of students in learning [1].

The goal of education in general is to improve the potential of students. It is normal, as a good teacher, that he wants as many of his students to pass or get good grades as possible. If many of his students score lower or don't graduate, he would be disappointed. In this scenario, teachers are required to grow the ability of children, they need to be clever to restrict themselves so that their motivation to produce high-scoring children [2].

A teacher's main role is to educate, meaning that the teacher not only shares information with students (Knowlegde), but also educates students in terms of attitudes and behavior [3]. In this scenario, educators are required to improve the capacity of children, they need to be intelligent in restricting themselves so that their ability to produce high-scoring children [2]. 
A teacher's main role is to educate, which means that the teacher not only shares information with learners (Knowlegde), but also educates learners in terms of attitudes and behavior [3].

\section{Method}

Identifying and explaining the application of classroom management to enhance the teaching standard of teachers at SMA Negeri 1 BabatSupat is the context of this study. The knowledge collected from this study came from the principal and teachers who taught to assess the teachers' application of classroom management in the learning process at SMA Negeri 1 BabatSupatIn order to supplement the study data, the researcher prepares interview sheets with the principal and teachers who teach, so that the collected data can be used as support material.

According to [4] qualitative techniques describe qualitative methods As a research technique that generates descriptive knowledge from people and observable actions in the form of written or spoken words. The resulting knowledge is in the form of sentences, photographs and human actions. [4] adds his view that qualitative research studies are studies performed through analyzing, observing,Research alone is the key data collection method and is performed in a natural setting or overall context.

"In a study data is needed. In collecting data, techniques are needed, both techniques in providing data, and techniques in classifying the data that has been collected. "Data is required in a study. Techniques are required in the collection of data, both techniques in the provision of data, and techniques in the classification of the collected data."the method used to collect data, while the data collection technique is the method used in carrying out the method that has been chosen."the method used to collect data, while the technique of data collection is the method used to execute the method chosen.

This research was performed using qualitative approaches and the following data collection techniques are used in this study:Wawancara atau Interview[5] notes that "An interview or interview is data where research is face to face with respondents in order to obtain the required data or information."Observation is characterized as systematic observation and recording of the symptoms that appear on the study object, according to [6]. Observations and notes are made on the symptoms that appear on items where the incident happens or the event occurs, such that the observer is with the entity being examined, which is called the empirical observation that the investigator would conduct in order to assess the teacher's application of classroom management in the SMA Negeri 1 BabatSupat learning method.

Documentation is a technique for the compilation of data in order to acquire written facts, including records, papers, archives and other written materials relevant to the research emphasis [7]. In the form of interview sheets and interview result sheets, the documentation used for data collection in this study is, In order to complement the study results, research permit, school profile and other supporting documents.

The process of organizing and sorting information into patterns, categories and simple description units is data processing, so that they can be found [6]. An analysis of qualitative data is an analysis that explains the overall study findings by means of,Organize information, organize it into usable units, synthesize it, scan for patterns and find them, find out what was important and what was learned, and decide what to share with others.

\section{Results and Discussions}

\section{Profile of schools}

Based on the data from the research results, SMA Negeri 1 BabatSupat is located at Km.86 Babat, Jalan Raya Palembang-Jambi. In 2006, SMA Negeri 1 BabatSupat was founded and run. SMA Negeri 1 BabatSupat was initially called SMA Negeri 2 Sungai Lilin along with the growth of the town, then SMA Negeri 2 Sungai Lilin On the basis of the 3Decree of the Regent of Musi Banyuasin, officially changed to SMA Negeri 1 Babat Supat with number: 022 of 2011 concerning the change of name for the State Junior High School / Senior High School / Vocational High School in Musi Banyuasin Regency.

Several educators with a total of 36 teaching staff assist in the learning process carried out at SMA Negeri 1 Babat Supat, It consists of 17 teachers from the PNS and 19 honorarium teachers. In addition, there are 13 educational staff members. While the number of students for 2020/2021 in SMA Negeri 1 Babat Supat was 510 students divided into 17 (Seventeen Rombel). 


\section{Vision and Mission}

Harmonizing education in the vision of SMA Negeri 1 BabatSupat is: "The realization of Indonesian people with character, achievement, competitive and environmentally friendly" In addition, the mission of the school is: (1) to instill a religious mindset, good character and leadership; (2) to generate quality teaching and learning activities accompanied by input from students, curriculum,Education staff, school administration, facilities and infrastructure, as well as the surrounding environment; (3) developing Adiwiyata school: (4) preparing students to be ready to follow and to succeed in science, sports and artistic skills; (5) creating a clean, green, beautiful, safe, comfortable and friendly environment; (6) promoting literacy programs to encourage a reading culture.

\section{Facilities and Infrastructure}

The following table data were collected on the basis of the results of observations of school facilities and infrastructure:

Table 1. Observation of the SMA Negeri 1 BabatSupat condition

\begin{tabular}{|c|c|c|c|c|}
\hline \multirow[t]{2}{*}{ No } & \multirow[t]{2}{*}{ Observation } & \multicolumn{3}{|c|}{ Observation Observation of Aspect } \\
\hline & & Good & Enough Good & Improvement needs \\
\hline 1 & Office of Principal & $\sqrt{ }$ & & \\
\hline 2 & Space Trainer & $\sqrt{ }$ & & \\
\hline 3 & Classroom with & $\sqrt{ }$ & & \\
\hline 4 & Space for libraries & $\sqrt{ }$ & & \\
\hline 5 & Space UKS & $\sqrt{ }$ & & \\
\hline 6 & Moushollah & $\sqrt{ }$ & & \\
\hline 7 & Facilities for Learning Resources & $\sqrt{ }$ & & \\
\hline 8 & Tools of Art & $\sqrt{ }$ & & \\
\hline 9 & Sports machinery & $\sqrt{ }$ & & \\
\hline 10 & Scout Space Gudep & $\sqrt{ }$ & & \\
\hline
\end{tabular}

\section{Analysis results}

Table 2. Implementation of Learning Instructor Management

\begin{tabular}{|c|c|c|c|c|c|c|c|}
\hline \multirow[t]{2}{*}{ No } & \multirow[t]{2}{*}{ The Observed Aspect } & \multicolumn{2}{|c|}{ Indicator } & \multicolumn{4}{|c|}{ Category } \\
\hline & & have & not & 1 & 2 & 3 & 4 \\
\hline 1 & Objectives for Learning & $\sqrt{ }$ & & & & $\sqrt{ }$ & \\
\hline 2 & Materials of study / materials of study & $\sqrt{ }$ & & & & $\sqrt{ }$ & \\
\hline 3 & Strategies for learning / Approaches & $\sqrt{ }$ & & & & $\sqrt{ }$ & \\
\hline 4 & Media To Learn & $\sqrt{ }$ & & & & $\sqrt{ }$ & \\
\hline 5 & Evaluation Assessment & $\sqrt{ }$ & & & & $\sqrt{ }$ & \\
\hline 6 & Open Lessons Skill & $\sqrt{ }$ & & & & $\sqrt{ }$ & \\
\hline 7 & The Learning Method Mindset of Teachers & $\sqrt{ }$ & & & & $\sqrt{ }$ & \\
\hline 8 & Mastery of Materials for Studying (Study Materials) & $\sqrt{ }$ & & & & $\sqrt{ }$ & \\
\hline 9 & $\begin{array}{l}\text { Activities to Educate and Understand (Learning } \\
\text { Process) }\end{array}$ & $\sqrt{ }$ & & & & $\sqrt{ }$ & \\
\hline 10 & Learning Media Capacity to Use & $\sqrt{ }$ & & & & $\sqrt{ }$ & \\
\hline 11 & Assessment of Learning & $\sqrt{ }$ & & & & $\sqrt{ }$ & \\
\hline 12 & Capacity to shut down learning experiences & $\sqrt{ }$ & & & & $\sqrt{ }$ & \\
\hline 13 & Following Up / Following Up & $\sqrt{ }$ & & & & $\sqrt{ }$ & \\
\hline 14 & Opening Activities for learning & $\sqrt{ }$ & & & & $\sqrt{ }$ & \\
\hline 15 & Learning Closing Operation & $\sqrt{ }$ & & & & $\sqrt{ }$ & \\
\hline 16 & $\begin{array}{l}\text { The behavior of teachers varies from the learning } \\
\text { stimulus }\end{array}$ & $\sqrt{ }$ & & & & $\sqrt{ }$ & \\
\hline 17 & Activity of the teacher in questioning skills & $\sqrt{ }$ & & & & $\sqrt{ }$ & \\
\hline 18 & Teacher operation in reinforcement provision & $\sqrt{ }$ & & & & $\sqrt{ }$ & \\
\hline
\end{tabular}

(source: SMA N 1 BabatSupat's interview) 
Based on the results of the learning process research in terms of the implementation of classroom management to improve the quality of teacher teaching at SMA Negeri 1 Babat Supat, which includes: 1) Learning Implementation Plan (RPP), 2) Teacher efficiency, 3) Opening and closing of teacher activities, 4) Teacher activities differ in learning stimuli,5) Teacher activities in questioning skills, 6) Teacher activities in providing reinforcement, it is recognized that the teacher's teaching implementation plan (RPP) can be said to be good and is in line with the developed curriculum, the presence of the teacher while teaching can be said to be good, open teacher activities and closing learning can be said to be good,It can be said that teacher behavior in questioning skills is good, and teacher activity in offering encouragement can be said to be good.

\section{Implementing Classroom Discipline}

To improve the standard of teaching for teachers at SMA Negeri 1 Babat Supat, there are many variables in the implementation of classroom management, namely:

\section{Classroom Management implementation in the learning process}

Implementing effective classroom management in learning where a teacher is able to understand classroom conditions as a learning atmosphere that enables students to improve their skills as optimally as possible, removing multiple barriers that can obstruct experiences with learning,Providing and organizing learning facilities and media that help and enable students to learn in accordance with the social, emotional and intellectual climate of the student, and can promote and direct students according to their various contexts of social, economic, cultural and character / character. Therefore, it is important to know the circumstances and issues that arise in the implementation of learning.

\section{Conduct in the administration of the classroom}

Any time there are concerns related to student attitudes and other external issues, a teacher attempts to find a solution such that the duties of the teacher work optimally. As an instructor at SMA Negeri 1, Ibu NysNurhayatiBabatSupat, a mathematics student, said:"Mom, there is always a problem any time learning takes place. So, to solve these challenges, there needs to be efforts and methods that we need to do. The instructor can search for background information on the issue if the problem that occurs is an individual problem.Help provide options, such as allowing students to meet with teacher counseling or homeroom teachers and encouraging students to be excited about them. In addition, the teacher often takes a personal approach, such as engaging with students and talking about learning challenges facing them, then the teacher motivates them.

\section{The acts of the instructor are in the form of avoidance and recognition of the conduct of the deviant learner.}

Furthermore, the moves that can be taken are to approach learners. To support learners in solving the problems at hand. In practice when, in effect, The teaching-learning process takes place, and there are also many issues that arise in groups, both individual problems and problems. The acts of students who are often lacking motivation, are busy and some annoy their mates, so the position of the approach of the teacher is required here. If an instructor does not comprehend the psychology of the student, however,The strategy followed would be the opposite of what is planned.

\section{Conditioning the environment of the climate / classroom}

The physical setting in which to learn has an important impact on learning outcomes in class management. The physical setting that meets the requirements facilitates the increasing strength of the learning process and has a positive impact on the achievement of objective learning.Have a broad understanding and can understand and have a detailed picture of how the teaching and learning process takes place, so a teacher must definitely pay attention to how to build an effective learning atmosphere in the management of the classroom, manage teaching and learning activities so that the teaching and learning process can function according to the goals.

For the teacher's competence as a boss. In this case, it is important for the instructor to be able to build a good environment or atmosphere, which means:

\section{Classroom with}

The classroom where the learning process takes place is very large and adequate, so that students can move freely and do not jostle, according to the statement made by Ms. Nys Nurhayati as a teacher at SMA Negeri 1 
Babat Supat.In the school, portraits of legends, words of wisdom and images of the President and Vice President were also decorated.

The space where the learning process takes place must allow students the freedom to move freely and not jostle and not compete with each other during learning activities between students who are one and the other. It is safer if the classroom is decorated with decorations, but given that the decoration includes educational values that can improve student awareness.

\section{Arrangement of Seating}

"According to Mrs. Nys Nurhayati's statement as a teacher at SMA Negeri 1 Babat Supat: "At some occasions, the arrangement of student seats is rendered according to the theme of the lesson, If the seats are adapted to the way they sit in groups when operating in groups, I do this so that students do not get lonely and bored, and if there are students who do not pay attention, they will certainly be caught

It is necessary to allow face-to-face arrangement of the most important seat. The teacher can then regulate student behavior and can also figure out which students pay attention and which students pay attention If the seats are adjusted to the way they sit in groups when working in groups, I do this so that students do not get lonely and bored, and if there are students who do not pay attention, they will certainly be caught

The most important seat is to allow face-to-face arrangement. The instructor can then monitor student actions and can also figure out which students are paying attention and which students are paying attention.

\section{Method for learning}

The method required by the teacher and its use differs in classroom management according to the objectives to be accomplished after learning ends. According to Mrs. NysNurhayati's comment as a teacher at SMA Negeri 1 BabatSupat: "The methods of learning used in teaching and learning activities vary. The method of learning I often use is cooperative."(Make a match (learning model by creating pairs, dependent learning, etc. The use of approaches is tailored to the learning material to be presented. I also also use direct examples to demonstrate to students in the delivery of material, so that students can easily grasp and understand the material being studied. If he does not master teaching techniques, an instructor would not be able to carry out his duties. Therefore, in choosing the right process, this is where teacher rivalry is required. By learning a range of techniques and being able to position themselves in situations and conditions that fit the circumstances of the student.

The usage of the mechanism must be capable of achieving extensive objectives, namely touching the cognitive,Students' affective and psychological realms, so that learning goals can be accomplished as planned.

Uses in the Media

Indeed, the use of media influences the circumstances and learning environments that educators organize and develop. "The media I use in learning is that I use books issued by the Ministry of Education and Culture and several reference books as support in the learning process" based on the clarification of Mrs. NysNurhayati as a teacher at SMA Negeri 1 BabatSupat. In the teaching and learning process, the use of educational media can create new expectations and interests, inspire and promote learning practices, and even lead to psychological impact on students.

\section{Patterns Of Contact}

Learning can be said to be successful in class management, if there is good interaction between teacher and student, based on Ms. NysNurhayati's narrative as a teacher at SMA Negeri 1 BabatSupat:If I finish explaining the lesson, for instance, there are still people who are puzzled and do not understand, I invite them to ask questions, and I also come to help me understand, and vice versa, the interaction between fellow students is also quite harmonious.'

The state of a close relationship between teacher and student, teacher and teacher, student and student, Through student learning, they can build passion and joy so that they have strong motivation and freedom to grow their own ways. In addition to interpersonal experiences in schooling, There must also be a pattern of interaction/good relationship between teachers and subject matter, namely teachers who are competent in teaching to effectively carry out the teaching and learning process, and interactions between students and subject matter, namely students who are involved and enthusiastic about learning. 


\section{Conclusions}

It can be said that the introduction of classroom management to enhance the teaching quality of teachers at SMA Negeri 1 Babat Supat is fine. The teacher's lesson plan (RPP) can be said to be good and is in line with the set curriculum, the presence of the teacher while teaching can be said to be good, the teacher's activities of opening and closing learning can be said to be good, It can be said that teacher engagement in questioning competencies is fine,And it can be said that teacher behavior in providing reinforcement is good. In the learning process, teachers are usually able to handle students. In general, teachers should arrange facilities in the learning phase, where the teacher uses such resources as a learning aid to assist the media. Not all teachers are able to develop a good environment for learning,Learning at midday (during the last hour of lessons) is not ideal, for example. Teachers are usually able to arrange the study room, Where Babat Supat is very conducive to the learning room at SMA Negeri 1 When learning takes place, the teacher is able to control the connection between teaching and learning events in the classroom. Teachers in learning planning are directed by the principal in order to respond to the 2013 curriculum in learning planning. In general, teachers at SMA Negeri 1 Babat SupatCarry out a learning process review that can be said to be successful. Limitations to enhance the teaching standard of teachers at SMA Negeri 1 Babat Supat faced by the implementation of classroom management, namely: (1) student conduct in learning often not all students pay attention to the material provided by the teacher; (2) the small number of supporting media in SMA Negeri 1 Babat Supat; (3) the learning environment is not conducive; terlambat terutama pada saat kegiatan pengajian setiap hari sebelum jam pelajaran di mulai. (4) In general, students are passive in answering the teacher's questions and following a certain learning process, in addition to the fact that students are normally noisy and critical in following the learning process; (5) in preparing to update the current curriculum in accordance with SMA Negeri 1 Babat Supat (6) instilling character in students (lack of discipline), where students sometimes still come, where the population is heterogeneous and the majority like Java, and students have thoughts and understandings that are not concerned with education.

\section{References}

Supentanginingrum, J. Instructor Specialist. Performance of teachers, Guidelines for certification and competency. Cet. Cet. I. Jogjakarta: Media Ar-Ruzz, 2013

Sukardi. In 2016. Essential to success in being a successful teacher. Strong teacher Kolbu: Bandung.

A, Rizaldi. In 2014. Towards Trained Teachers from Traditional Teachers. Grasindo: Jakarta.

Moleong, to L. In 2011. Methodology for Qualitative study. Bandung: Rosdakarya Kids.

Sugiyono In 2015. Methods of educational analysis, quantitative methods, qualitative and R \& D approaches. Alfabeta: Bandung.

Arikunto, S, 2010. A Rehearsal Strategy, Analysis Method. Edition Revised. Jakarta: Cipta Rineka.

Djamarah. In 2012. Teachers and Students in Interaction with Schooling. Jakarta: Cipta Rineka. 